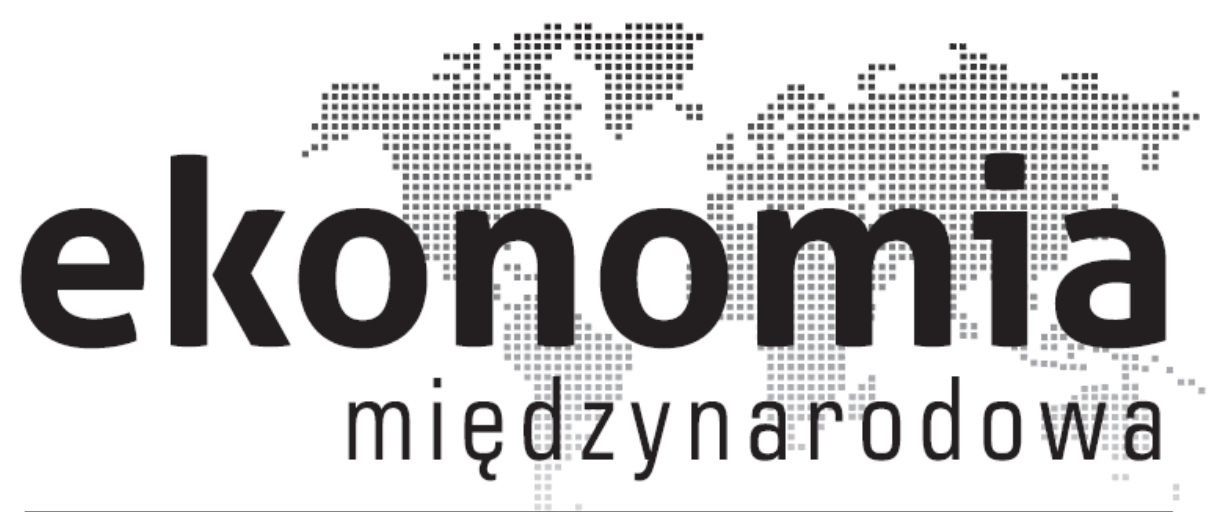

Ekonomia Międzynarodowa

Nr 14 (2016)

Wydawca: Uniwersytet Łódzki

(Publisher: University of Lodz)

www.ekonomia-m.pl

ISSN: 2082-4440 - wydanie papierowe (paper edition)

ISSN: 2300-6005 - wydanie elektroniczne (electronic edition)

Wersja elektroniczna czasopisma jest wersją referencyjną

(Electronic edition is the reference version of the journal)
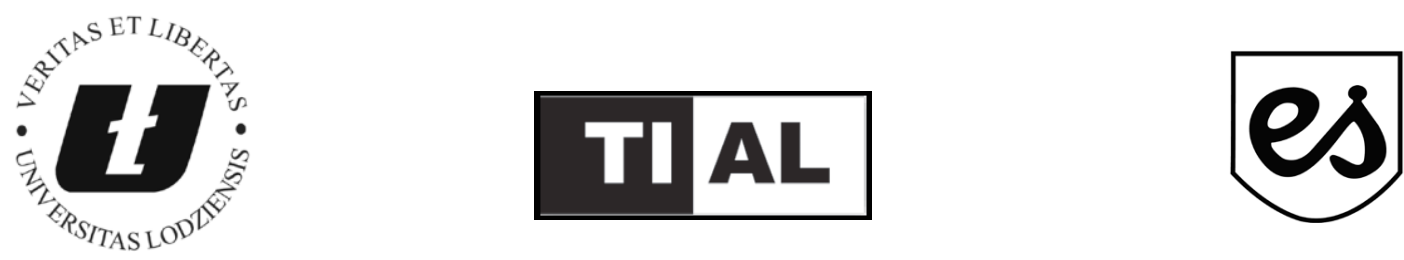


\section{Institutional Complementarity of Poland in Terms of Diversity of Capitalism}

Maciej Wysocki*

\section{Introduction}

There is a consensus among institutional economists of all kinds in the statement that institutions do matter [Williamson, 2000, p. 595]. The quality of institutions has agreat impact upon economic performance, which has been revealed recently in transition economies in Central and Eastern Europe (Gross \& Steinherr, 2005, p. 327). One of the first definitions of institutions was proposed by North, who pointed out that institutions should be considered the rules of the game of a society (...) the humanly devised constraints that structure human interaction. They are made up of formal constraints (rules, laws, constitutions), informal constraints (norms of behaviour, conventions, and self-imposed codes of conduct) and their enforcement characteristics (North 1990. p. 3).

However, there are still difficulties in measuring the performance of institutions (Amable 2003, p. 5). Determinants of institutions tend to be very susceptible to analysis using the traditional measures of economic theory (Matthews 1986, p. 903). It is especially worth noting that the efficiency of institutions in a specific domain cannot be appreciated independently of the effects that they have in other domains (Amable 2003, p. 6). That is why the research method in this essay is rooted in the concept of institutional complementarity, which involves the assumption that there is an interaction between several institutions (Amable 2003, pp. 5-6).

The economic transition from a socialist centralized system to a free-market economy which took place in Central and Eastern Europe after 1989 should be seen as an event of historical significance (Kolodko \& Rutkowski 1991). However, the transition process in Poland did not finish with the introduction of Wilczek-Rakowski's law in 1988 or the implementation of Balcerowicz's plan in 1989,

\footnotetext{
*Maciej Wysocki - MSc, Warsaw School of Economics, Collegium of World Economy.
} 
despite the fact that those economic reforms were the cornerstone of Poland's transition. The second phase of economic transition was connected with the accession to the European Union, which took place in 2004. From the point of view of an institutional framework, this forced Poland to some extent to become more similar to the other countries of the old European Union. However, the case of Poland is a little bit different than other countries from the peer group (e.g. Hungary or the Czech Republic) because, at least at the first stage of the economic transition Poland, decided to choose shock therapy (Kolodko \& Rutkowski 1991). Taking into account the theory of 'path dependence' this could have been a factor that had a large impact upon Poland's institutional architecture (Arthur, 1994).

At this stage we will not analyse the whole economic transition process of Poland, instead we will focus on the assessment how Poland's institutional framework works nowadays, almost 25 years after the first economic reforms, in terms of institutional complementarity.

\section{Theoretical assumptions of institutional complementarity}

The general concept of institutional complementarity is based on the idea that two institutions can be perceived as complementary when one institution increases the efficiency of the other (Amable 2003, p. 6). The key idea of this approach is the assumption that an interaction exists between two or more institutions and that is the reason why institutions cannot be analysed separately (Aoki 1994; Amable 2003, p. 55).

In a more formal way institutional complementarity can be represented by a differential definition. In such an approach we should consider an aggregate 'performance' function $F(.,$.$) and at least 2$ institutional areas, $X$ and $Y$, associated with specific institutional forms, $x$ and $y$, respectively. If $x$ and $y$ are continuous, and $F$ is differentiable, then the definition of complementarity in economics is represented by the following inequality (Amable 2003, p. 61-62).

$$
\frac{\partial^{2} F(x, y)}{\partial x \partial y} \leq 0
$$

However, the above inequality is adequate only for the case of continuous variables. In a real economic environment, we can usually distinguish the limited number of institutional forms. Complementarity in such cases is associated with the notion of supermodularity (Topkis 1998; Amable 2003, p. 62; Yildiz 2010).

Let's assume that we have:

$$
\begin{aligned}
& P_{1}=\left(x_{1}, y_{2}\right), P_{2}=\left(x_{2}, y_{1}\right) \\
& P_{1} \vee P_{2}=\left(\max \left(x_{1}, x_{2}\right), \max \left(y_{2}, y_{1}\right)\right) \\
& P_{1} \wedge P_{2}=\left(\min \left(x_{1}, x_{2}\right), \min \left(y_{2}, y_{1}\right)\right)
\end{aligned}
$$


Then, the definition of supermodularity can be described as follows (Yildiz 2010, p. 6):

$$
\begin{aligned}
& \forall P_{1}, P_{2} \in L^{2} \\
& f\left(P_{1} \vee P_{2}\right)+f\left(P_{1} \wedge P_{2}\right) \geq f\left(P_{1}\right)+f\left(P_{2}\right)[1.1]
\end{aligned}
$$

In particular, if we assume that:

$$
\mathrm{x}_{2} \geq \mathrm{x}_{1}, \mathrm{y}_{2} \geq \mathrm{y}_{1}
$$

Then

$$
\begin{aligned}
& P_{1} \vee P_{2}=\left(x_{2}, y_{2}\right) P_{1} \wedge P_{2}=\left(x_{1}, y_{1}\right) \\
& f\left(x_{2}, y_{2}\right)+f\left(x_{1}, y_{1}\right) \geq f\left(x_{1}, y_{2}\right)+f\left(x_{2}, y_{1}\right)[1.2] \\
& f\left(x_{2}, y_{2}\right)-f\left(x_{1}, y_{2}\right) \geq f\left(x_{2}, y_{1}\right)-f\left(x_{1}, y_{1}\right)[1.3]
\end{aligned}
$$

Roughly speaking, the marginal contribution of enlarging the first input from $\mathrm{x}_{1}$ to $\mathrm{x}_{2}$ given $\mathrm{y}_{2}$ is larger than the marginal contribution of enlarging the first input from $\mathrm{x}_{1}$ to $\mathrm{x}_{2}$ given $\mathrm{y}_{1}$.

In particular, if we assume that we have two institutional areas $(X, Y)$ and three institutional forms in each case $\left(\mathrm{x}_{1}, \mathrm{x}_{2}, \mathrm{x}_{3}\right)$ and $\left(\mathrm{y}_{1}, \mathrm{y}_{2}, \mathrm{y}_{3}\right)$, respectively, and institutional forms are ordered, then our lattice consists of 9 points (see Matrix 1):

\section{Matrix 1}

\begin{tabular}{|l|c|c|c|}
\cline { 2 - 4 } \multicolumn{1}{c|}{} & \multicolumn{3}{|c|}{$\mathrm{X}$} \\
\hline \multirow{3}{*}{$\mathrm{Y}$} & $\mathrm{P} 1=(\mathrm{x} 1, \mathrm{y} 1)=(1,1)$ & $\mathrm{P} 2=(\mathrm{x} 2, \mathrm{y} 1)=(2,1)$ & $\mathrm{P} 3=(\mathrm{x} 3, \mathrm{y} 1)=(3,1)$ \\
\cline { 2 - 4 } & $\mathrm{P} 4=(\mathrm{x} 1, \mathrm{y} 2)=(1,2)$ & $\mathrm{P} 5=(\mathrm{x} 2, \mathrm{y} 2)=(2,2)$ & $\mathrm{P} 6=(\mathrm{x} 3, \mathrm{y} 2)=(3,2)$ \\
\cline { 2 - 4 } & $\mathrm{P} 7=(\mathrm{x} 1, \mathrm{y} 3)=(1,3)$ & $\mathrm{P} 8=(\mathrm{x} 2, \mathrm{y} 3)=(2,3)$ & $\mathrm{P} 9=(\mathrm{x} 3, \mathrm{y} 3)=(3,3)$ \\
\hline
\end{tabular}

Then it is obvious that for every pair of points from the lattice which is located in the same column or row, the condition of supermodularity is fulfilled, because the transformed points are equal to the input points. For instance, let's consider $\mathrm{P}_{1}$ and $\mathrm{P}_{7}$ :

$$
\begin{aligned}
& P_{1}=\left(x_{1}, y_{1}\right), P_{7}=\left(x_{1}, y_{3}\right) \\
& P_{1} \vee P_{7}=\left(\max \left(x_{1}, x_{1}\right), \max \left(y_{1}, y_{3}\right)\right)=\left(x_{1}, y_{3}\right) \\
& P_{1} \wedge P_{7}=\left(\min \left(x_{1}, x_{1}\right), \min \left(y_{1}, y_{3}\right)\right)=\left(x_{1}, y_{1}\right)
\end{aligned}
$$

Then:

$$
f\left(P_{1} \vee P_{7}\right)+f\left(P_{1} \wedge P_{7}\right) \geq f\left(P_{1}\right)+f\left(P_{7}\right)
$$

Thus

$$
f\left(x_{1}, y_{3}\right)+f\left(x_{1}, y_{1}\right) \geq f\left(x_{1}, y_{1}\right)+f\left(x_{1}, y_{3}\right)
$$


Obviously, the same situation occurs for each pair of points in which one of them has both coordinates less or equal than the other.

If we consider two points that create a section in the matrix, we can distinguish the following cases:

Case 1

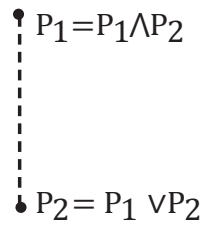

Case 2

Case 3

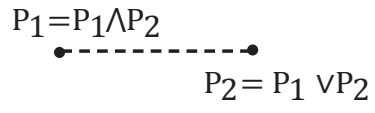

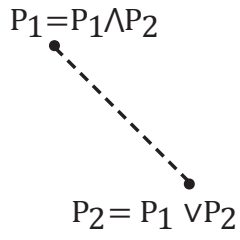

Case 4

For the cases (1-3) obviously inequality [1.1] is satisfied, because:

$$
f\left(P_{1} \vee P_{2}\right)+f\left(P_{1} \wedge P_{2}\right)=f\left(P_{2}\right)+f\left(P_{1}\right)
$$

Then, the only case that should be checked is that, which depicts the section with a positive slope (case 4), because according to inequality [1.1] the left-hand side of this inequality could not be grater or equal to the right-hand side.

Generally, the total number of combinations of all pairs in a matrix of dimensions $\mathrm{d} \times \mathrm{d}$ is

$$
\overline{C_{d^{2}}^{2}}
$$

In particular, regarding Matrix 1 it is

$$
\overline{C_{9}^{2}}=\left(\begin{array}{c}
9+2-1 \\
2
\end{array}\right)=\left(\begin{array}{c}
10 \\
2
\end{array}\right)=45
$$

When it comes to the pairs in columns and rows, the total number of combinations is:

$$
\overline{C_{d}^{2}} \cdot 2 d-d^{2}
$$

Thus, in Matrix 1, it amounts to:

$$
\overline{C_{3}^{2}} \cdot 2 \cdot 3-3^{2}=\left(\begin{array}{c}
3+2-1 \\
2
\end{array}\right) \cdot 6-9=27
$$

In turn, regarding pairs creating sections with a negative and positive slope, the total number of combinations is:

$$
s=\overline{C_{d^{2}}^{2}}-\left(\overline{C_{d}^{2}} \cdot 2 d-d^{2}\right)
$$

Then the total number of combinations of pairs creating sections with a positive slope (for which the function $\mathrm{f}$ is suspected not to be supermodular) equals to $s_{+}=\frac{s}{2}$. 
Hence, for Matrix 1, we have:

$$
s_{+}=\frac{1}{2}\left[\left(\overline{C_{d^{2}}^{2}}\right)-\left(\overline{C_{d}^{2}} \cdot 2 d-d^{2}\right)\right]=\frac{1}{2}(45-27)=9
$$

Supermodularity will be checked for these 9 pairs in this essay.

So for Matrix 1, considering only sections with a positive slope (case 4), the measure of institutional complementarity can be described as a ratio of the number of cases for which condition [1.1] is satisfied and the number of all cases of sections with a positive slope (case 4). The Institutional Complementarity Ratio is calculated as follows:

$$
I C R=\frac{c}{S_{+}}=\frac{c}{9}
$$

where

$\mathrm{c}$ - number of pairs of points in the matrix (lattice) which create sections with a positive slope and satisfy condition [1.3].

\section{Data selection, presentation and statistical transformation}

With the aim of examining the institutional complementarity of Poland, cross-sectional data for 34 OECD countries from the years 2011-2012 from four different institutional areas was collected: social protection, labour market, financial system and education. Such a selection of institutional areas is partially rooted in Amable's approach (Amable 2003) However, at this level of analysis one institutional domain (product market) has been omitted due to the slightly different specifics of this market in terms of interaction with other domains. The key idea of such a choice of institutional domains was strictly connected to their impact upon the Human Development Index (HDI), which is the measure of chances of individuals being able to realize their innate capabilities (Sen 2007, p. 270). We assume that the influence of the regulations of the product market upon HDI are less clear than other institutional areas. Below we describe the interactions and interdependencies among the chosen institution domains.

The scope of social protection interacts in obvious manner with the labour market. The greater power of trade unions ceteris paribus, the higher minimum wage is. As a result, higher unemployment causes a higher level of income redistribution (jobless claims) (Friedman \& Friedman 1979).

Social protection also influences the financial system. The transmission channel in this case is the tax burden and is associated with the problem of the efficiency-equity trade-off (Krugman, Wells 2005). A higher level of income redistribution can evoke higher taxes. Levine found out that direct and indirect taxes associated with stock-exchange market transactions slow real output growth per capita (Levine 1990). 
Social protection interacts with the education system. However, the link here is quite unintuitive. General, non-vocational education systems are more likely to create a poverty trap, which influences the social protection area. The idea behind this is as follows: in competitive vocational training systems, students have natural incentives to be as good as they can with the aim of getting the most valuable training programs that can provide them with the best career prospects. In contrast, general education systems usually offer students relatively fewer opportunities for improving their value on the labour market. As a result, they could be more dependent on social protection in the future (Estevez-Abe, Iversen, Soskice 2001). That relationship is quite unintuitive, because it could be assumed that general education systems can provide more adaptability skills that could help students to adjust to the constantly changing world.

Interaction between the labour market and the financial system is as follows: increased market capitalization as well as decreased banking concentration reduce unemployment if the level of labour market regulation, union density and coordination in wage bargaining is low (Gatti, Rault, Vaubourg 2010).

Another interaction can be observed between the labour market and the education system. A flexible labour market (low influence of trade unions) facilitates employee mobility and in such a case comprehensive educational systems are preferred. Conversely, in a rigid labour market (relatively strong trade unions) more specific educational systems are preferred (Amable 2003, p. 61).

The last interaction is between the financial system and education. In the case where the main source of capital is from the banking sector, long-term investment projects are established, which favours more vocational education systems. Otherwise, when the main source of capital is the stock-exchange, then short-term investment projects are preferred, which determines that more general education systems are in favour (Amable 2003, p. 61).

All of the above institutional domains and their interactions have an impact on people's capabilities and functioning, which in turn influences HDI (see Figure 1).

Figure 1. Conceptual scheme of institutional frame work and its influence upon HDI

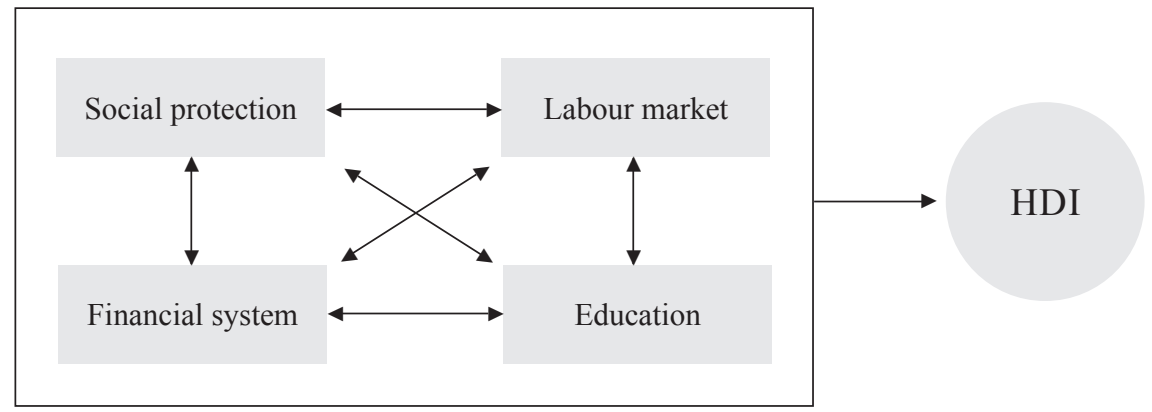

Source: own. 
Below is the list of institutional areas and corresponding variables and the endogenic variable (HDI) in the entry data set (see Table 1).

Table 1. Entry dataset

\begin{tabular}{|c|c|c|c|}
\hline Institutional area & Variables & Abbreviation & Source \\
\hline Social protection & $\begin{array}{l}\text { Gini coefficient of household market and } \\
\text { disposable incomes in } 2011\end{array}$ & Gini & OECD \\
\hline Labour market & Trade union density in 2012 & TUD & OECD \\
\hline Financial system & $\begin{array}{l}\text { Market capitalization of companies on } \\
\text { stock exchange in } 2012(\% \text { of GDP) }\end{array}$ & MCAP & World Bank \\
\hline Education & $\begin{array}{l}\text { The share of enrolment in vocational } \\
\text { programmes in secondary schools }\end{array}$ & VE & UNESCO \\
\hline Endogenic variable & $\begin{array}{l}\text { Human Development Index - summary } \\
\text { measure of average achievement in key } \\
\text { dimensions of human development: a long } \\
\text { and healthy life, being knowledgeable and } \\
\text { have a decent standard of living, } 2012\end{array}$ & HDI & $\begin{array}{l}\text { United } \\
\text { Nations } \\
\text { Development } \\
\text { Programme } \\
\text { Database }\end{array}$ \\
\hline
\end{tabular}

Figure 2. Gini coefficient of household market and disposable incomes in 2011

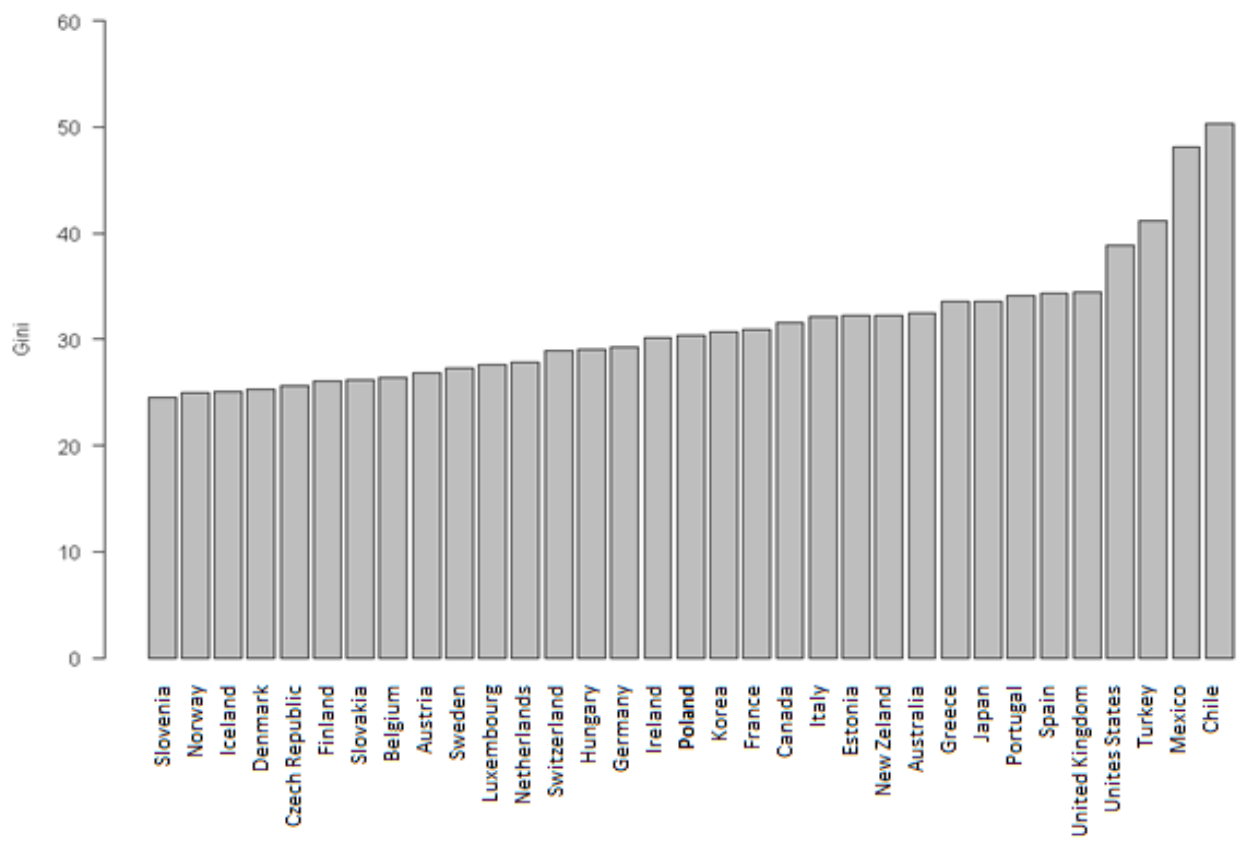

Source: OECD. 
A quick glance at the rough data can provide interesting insights (see Figure 2). We can observe that in terms of redistribution of income (the Gini coefficient), Poland, with a value of 0.304 , is in the middle of the ranking. The most equal societies are in Slovenia, with a Gini coefficient of 0.245 , and Nordic countries (Norway, Iceland, Denmark) with a Gini coefficient between 0.2496 and 0.257. Conversely, the most unequal societies in terms of income redistribution are in Latin American countries i.e. Mexico and Chile, with a Gini coefficient between 0.482 and 0.503 , respectively. The median and mean in the sample amount to 0.305 and 0.315 , respectively.

Figure 3. Trade union density in 2012 (percentage)

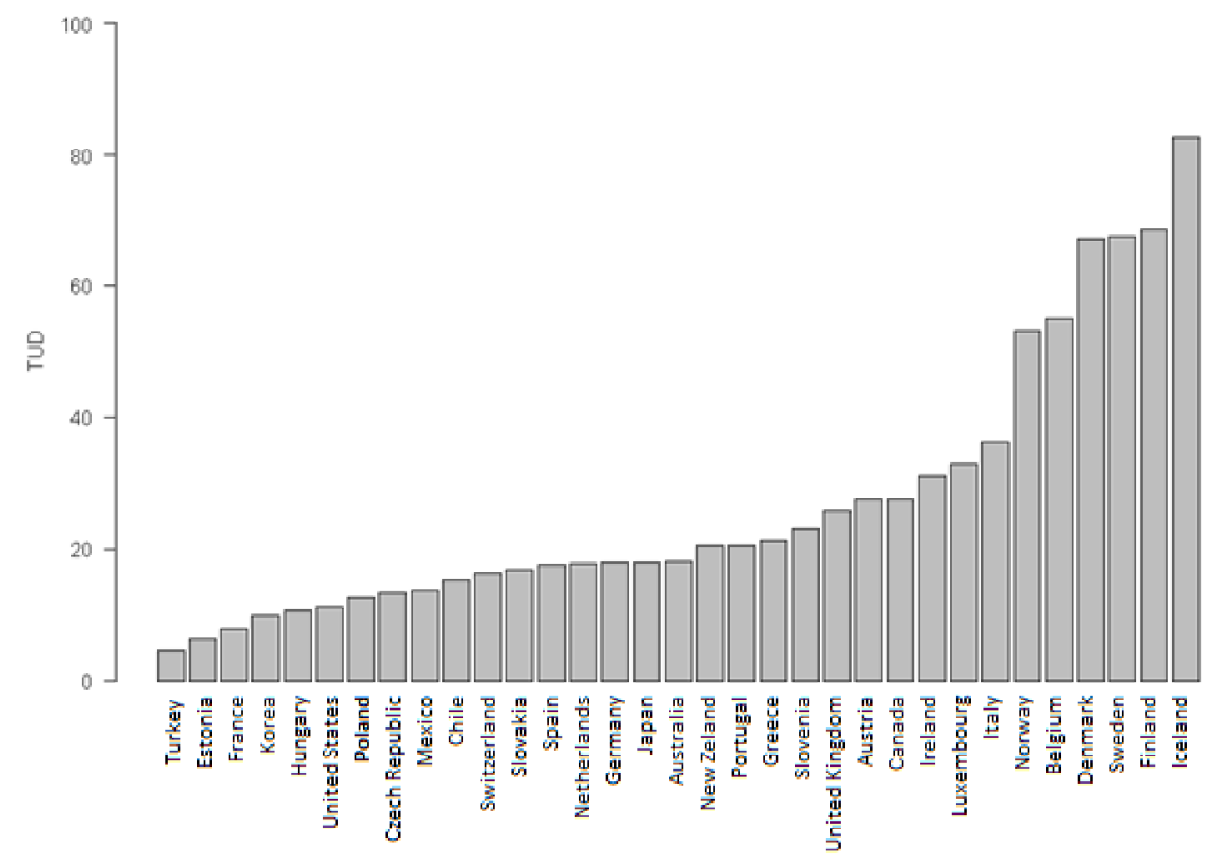

Source: OECD.

On Figure 3 we can observe that the relative strength of trade unions in Poland is the 7th lowest in OECD countries. Trade union density in Poland amounts to 0.125 . The lowest trade union density can be observed in Turkey and Estonia with values of 0.045 and 0.064 , respectively. On the other hand, the most powerful trade unions are in Nordic countries (Denmark, Sweden, Finland and Iceland) with values between 0.672 and 0.826 . The median and mean in the sample amount to 0.182 and 0.269 , respectively.

In Figure 4 the market capitalization of companies at stock exchange as a percentage of GDP is depicted. We can assess that in the case of Poland this value is 
not very high (35.8\%) compared to the leaders (UK, US, Chile), where this value ranges from $115.5 \%$ to $117.7 \%$. The cases of Luxembourg and Switzerland are outliers, because those countries are tax havens, and that is the reason for such a huge share of market capitalization in relation to GDP. However, it is worth noting that Poland is ahead in this area compared to other countries from the peer group, such as Hungary, the Czech Republic or Slovakia. The median and mean in the sample amount to $54.1 \%$ and $60.3 \%$, respectively.

Figure 4. Market capitalization of listed companies (\% of GDP) in 2012

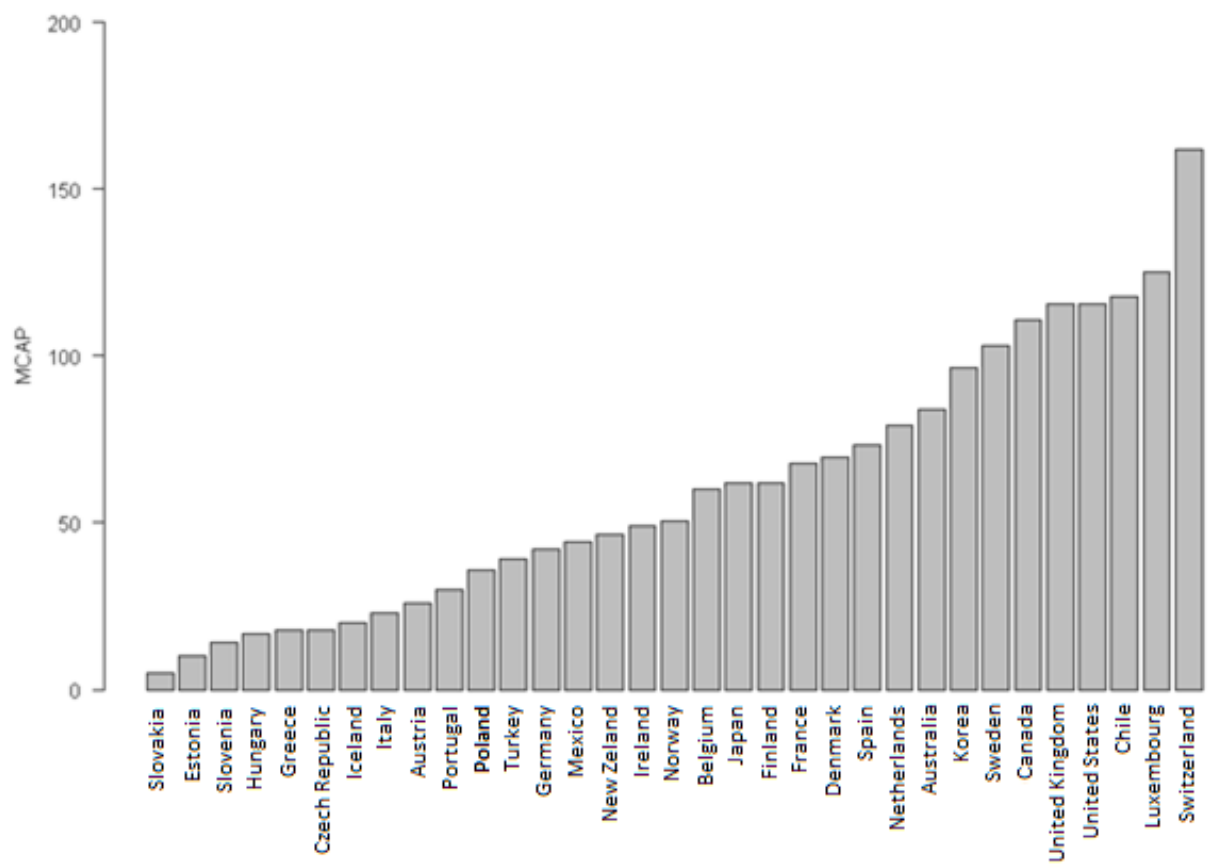

Source: World Bank.

In Figure 5 we can see the scope of specialization in education systems. The most general education system is in the United Kingdom, where the share of enrolment in vocational secondary schools reached $9.7 \%$. The most vocational education system is in the Netherlands (48.25\%). The Polish education system, with a $29.3 \%$ share of enrolment in vocational schools, is in the middle of the ranking. The median and mean in the sample amount to $24.4 \%$ and $25.5 \%$, respectively.

Figure 6 suggests that HDI in Poland (0.834) is at relatively low level compared to other OECD countries. The highest HDI can be found in Switzerland, Australia and Norway, with the range between 0.917 and 0.944 . On the other hand, Mexico and Turkey have the lowest HDI, with a range between 0.756 and 0.759 . The median and mean in the sample amount to 0.8825 and 0.874 , respectively. 
Figure 5. Share of enrolment in vocational secondary schools in 2012, both sexes (percentage)

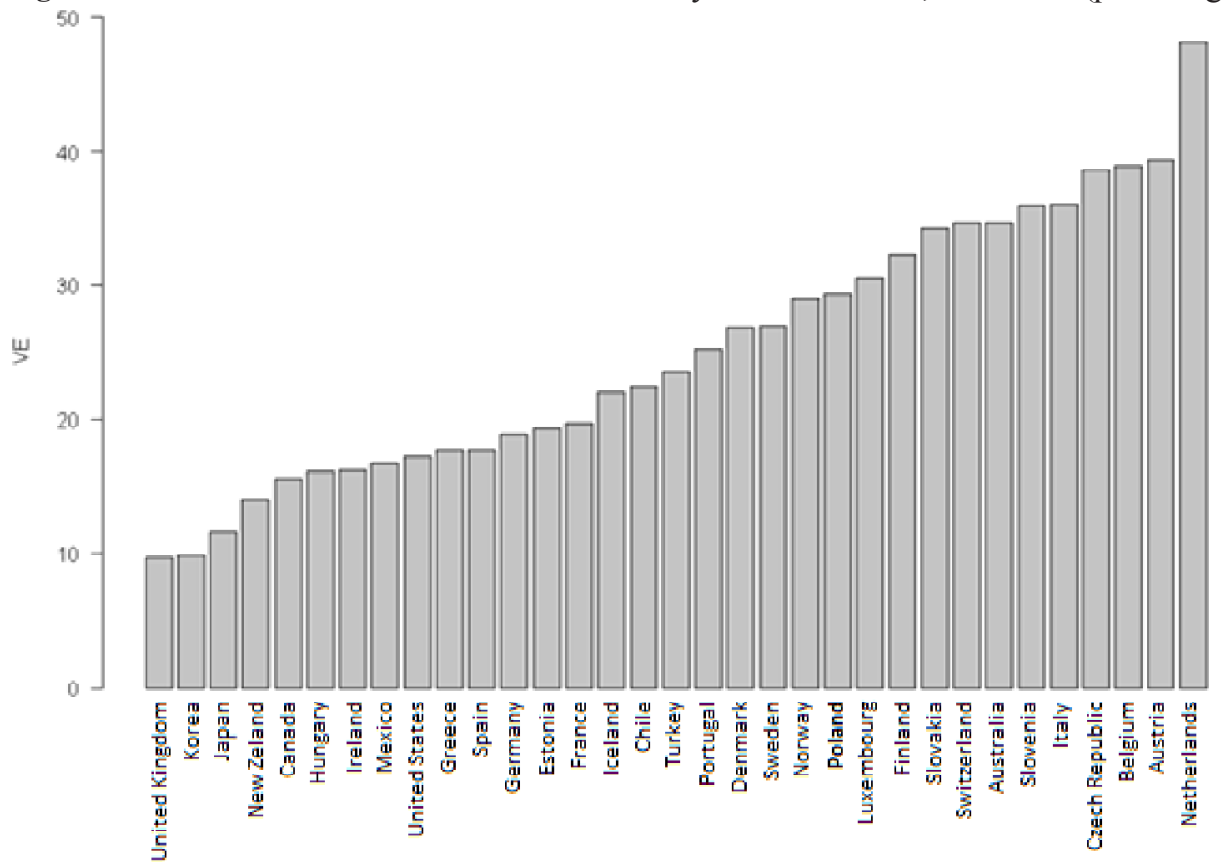

Source: UNESCO.

Figure 6. Human Development Index in 2013

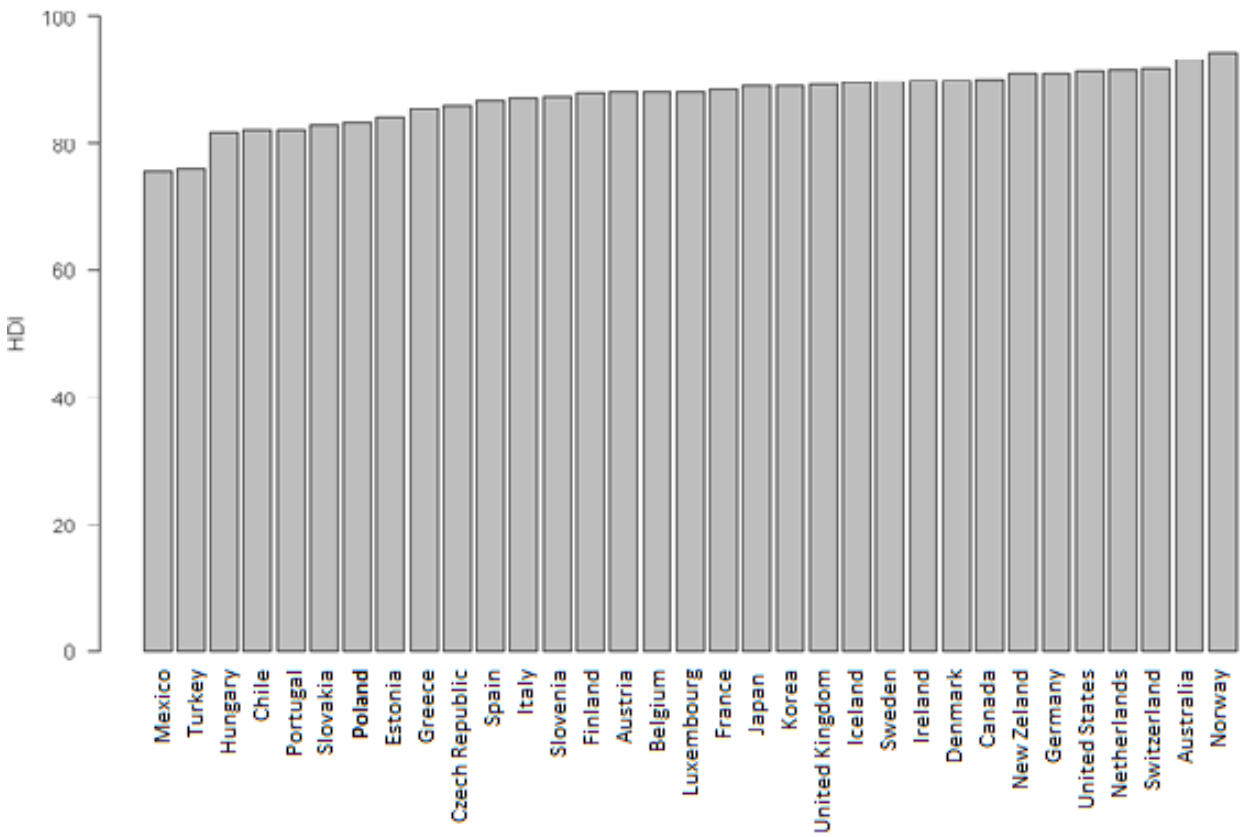

Source: United Nations Development Programme Database. 
The next step in the data analysis is clustering, using Principal Component Analysis with the aim of finding 5 clusters that could correspond to the 5 types of capitalism known from the DoC approach.

Figure 7. Variables factor map (PCA)

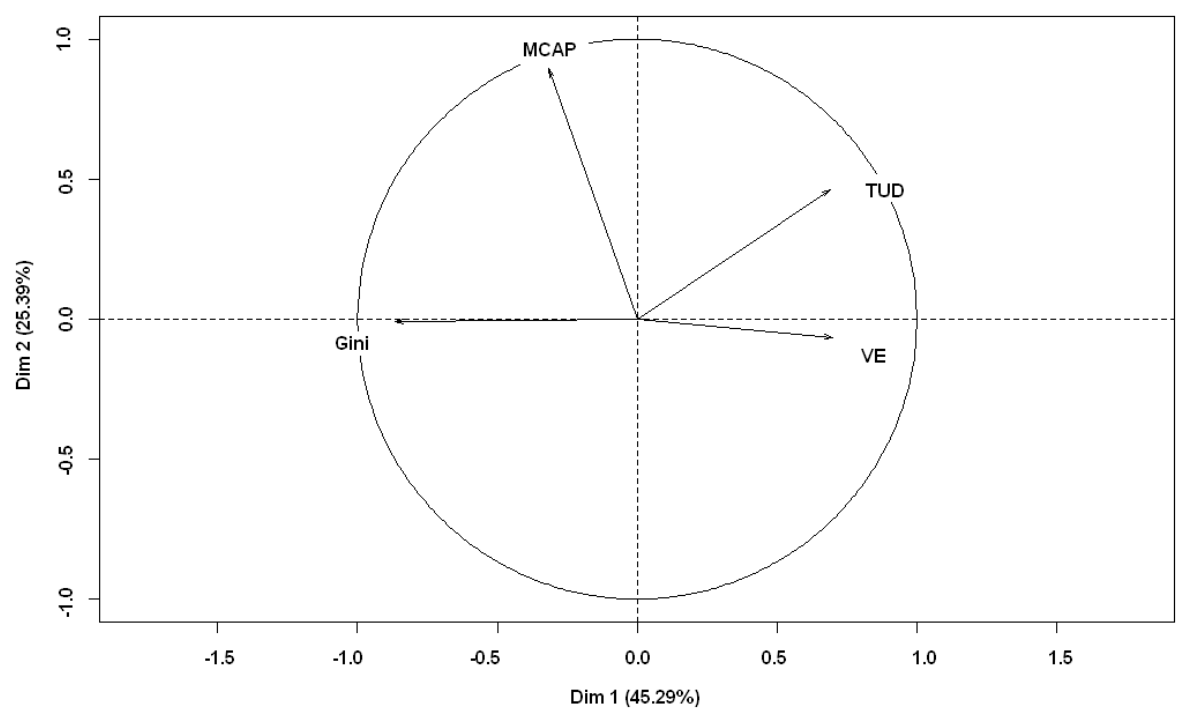

Source: own.

Figure 8. Individuals factor map (PCA)

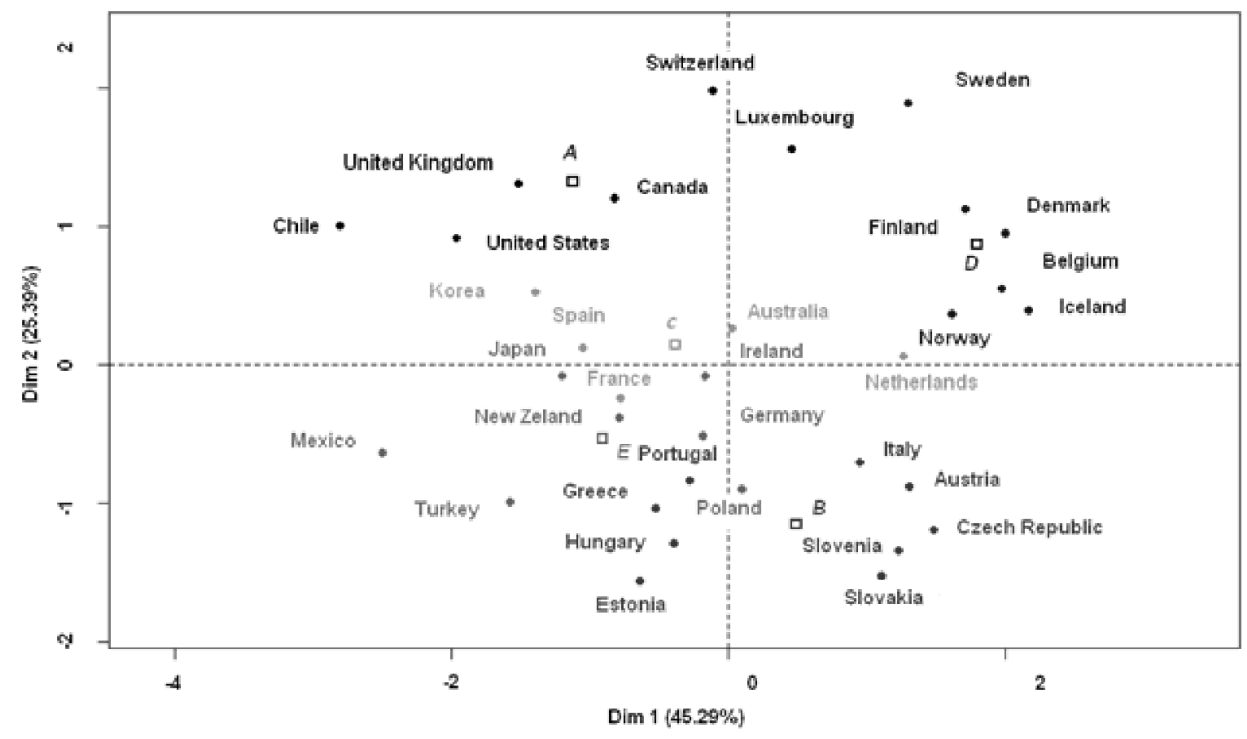

Source: own elaboration. 
The variables factor map (see Figure 7) suggests that the four variables are not correlated. The angle between two arrows represents the correlation between respective variables. There is no linear dependence if the angle is 90 degrees (Hoffman 2010, p. 6). Furthermore, the Principal Component Analysis procedure reduced the primary dimensions to only two factors that explain $70 \%$ of the total variance above, which can be regarded as a satisfactory level.

The cloud of points on the individual factor map (see Graph 8) was generated by Principal Component Analysis. This statistical procedure reduced 4 dimensions (Gini, MCAP, TUD, VE) into 2 principal components, which explains $70.68 \%$ of the variance of the variables. In the next step, through the Hartigan-Wong algorithm, 5 centres of potential clusters (A, B, C, D, E) were generated. Finally, every point was assigned to the one of those 5 centres according to the $\mathrm{K}$-mean algorithm. In this procedure, the distance of every point to every centre is determined in terms of the sum of the squares of the coordinates' differences. As a result, every point is assigned to the centre to which the distance is the smallest.

It turned out that those 5 clusters are consistent to a large degree with the Diversity of Capitalism theory. Clusters A (Canada, Chile, Luxembourg, United Kingdom, United States, Switzerland, see Graph 8) and D (Belgium, Denmark, Finland, Iceland, Norway, Sweden) correspond to Bruno Amable's approach with two models: the Anglo-Saxon model (market-based economy) and the Nordic model (Amable 2003, p. 225). Cluster B is a combination of the Mediterranean capitalism model (Greece, Portugal, Italy) and the former socialist countries (the Czech Republic, Slovakia, Hungary, Slovenia and Estonia). Cluster C is a combination of three continental countries (Spain, France and the Netherlands) accompanied by Korea and Australia. The last cluster, cluster E, consists of some highly developed countries such as Germany, Ireland, Japan and New Zealand, on the one hand, and of some of the most dynamic emerging market economies such as Poland, Mexico and Turkey on the other.

Surprisingly, Principal Component Analysis, the Hartigan-Wong algorithm and the K-mean method suggest that Poland, in terms of institutional framework, is not so close to other former socialist countries like the Czech Republic or Hungary. From that point of view, Poland can be viewed as a unique case of a transition country.

The last step at this level of analysis is data transformation to the final analysis of institutional complementarity (building matrices of institutional complementarity). We have to carry out two statistical procedures: normalization and categorization.

We normalized all the data in each institutional domain according to the following formula:

$$
x_{n}=\frac{x-x_{\min }}{x_{\max }-x_{\min }}
$$


After that, all data in each institutional domain was transformed into discretional data with 3 categories (3 institutional forms), while HDI (endogenic variable) was transformed into discretional data with 9 categories (see Appendix 2).

\section{Results}

Because of the fact that all the data were transformed into ordered, discretional variables, we were able to analyse how the particular configuration of each two institutional areas can affect the level of HDI (our endogenic variable). To achieve this aim, we built the matrices of complementarity for each possible configuration of two institutional areas. Every row and column of the matrices corresponds to one of the three institutional forms, so the intersection indicates a specific combination of two particular institutional areas. As the output of such an intersection, we have the specific level of HDI estimated through K-Nearest Neighbours Method. However, one point in every matrix is not an estimated level of HDI, but it corresponds to the empirical level of Poland's HDI.

With such matrices, we can check the condition of supermodularity for the 9 suspected points (see paragraph 2) and then calculate the Institutional Complementarity Ratio (ICR, see paragraph 2). However, in the algorithm of the K-Nearest Neighbours Method, the results are not entirely deterministic, so we conducted 1000 simulations for each interaction of two institutional forms with the aim of assessing the average level of ICR.

Below are the results for the 6 cases of interaction between institutional areas.

Case 1. Social protection vs. labour market

\begin{tabular}{|c|c|c|c|c|}
\cline { 3 - 5 } \multicolumn{2}{c|}{} & \multicolumn{3}{c|}{ Labour market } \\
\cline { 3 - 5 } \multicolumn{2}{c|}{} & $\mathrm{x}_{1}$ & $\mathrm{x}_{2}$ & $\mathrm{x}_{3}$ \\
\hline \multirow{3}{*}{ Social protection } & $\mathrm{y}_{1}$ & 4 & 6 & 6 \\
\cline { 2 - 5 } & $\mathrm{y}_{2}$ & 7 & 6 & 7 \\
\cline { 2 - 5 } & $\mathrm{y}_{3}$ & 4 & 4 & 7 \\
\hline
\end{tabular}

$C R=0.667$

In the case of Poland, we have relatively strong social protection $\left(y_{1}\right)$ and weak trade unions $\left(x_{l}\right)$. The Institutional Complementarity Ratio amounts to 0.667. 
Figure 9. Social protection vs. labour market. Distribution of ICR after 1000 simulations

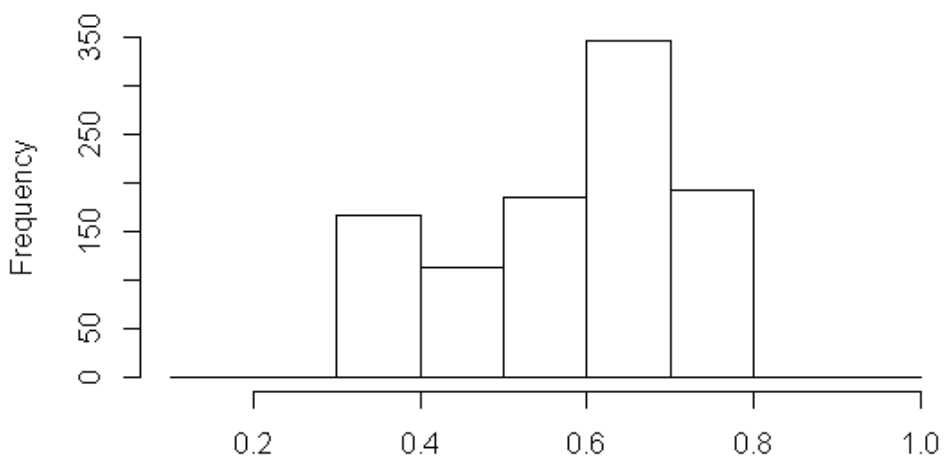

$I C R 1000=0.5873$

The average Institutional Complementarity Ratio after 1000 simulations amounts to 0.5873 .

Case 2. Social protection vs. financial system

\begin{tabular}{|c|c|c|c|c|}
\cline { 3 - 5 } \multicolumn{2}{c|}{} & \multicolumn{3}{c|}{ Financial system } \\
\cline { 3 - 5 } \multicolumn{2}{c|}{} & $\mathrm{x}^{1}$ & $\mathrm{x}_{2}$ & $\mathrm{x}_{3}$ \\
\hline \multirow{3}{*}{ Social protection } & $\mathrm{y}_{1}$ & 4 & 7 & 7 \\
\cline { 2 - 5 } & $\mathrm{y}_{2}$ & 6 & 7 & 7 \\
\cline { 2 - 5 } & $\mathrm{y}_{3}$ & 1 & 7 & 7 \\
\hline
\end{tabular}

$I C R=0.556$

In the case of Poland, we have relatively strong social protection $\left(y_{1}\right)$ and no excessive role of the stock exchange $\left(x_{1}\right)$. The Institutional Complementarity Ratio amounts to 0.556 .

Figure 10. Social protection vs. financial system. Distribution of ICR after1000 simulations

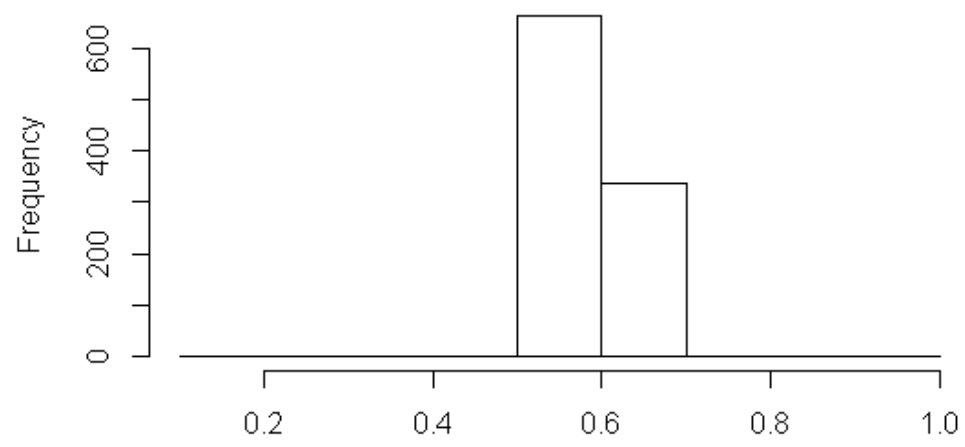

$I C R_{1000}=0.593$ 
The Average Institutional Complementarity Ratio after 1000 simulations amounts to 0.593 .

Case 3. Social protection vs. education

\begin{tabular}{|c|c|c|c|c|}
\cline { 3 - 5 } \multicolumn{2}{c|}{} & \multicolumn{3}{c|}{ Education system } \\
\cline { 3 - 5 } \multicolumn{2}{c|}{} & $\mathrm{x}_{1}$ & $\mathrm{x}_{2}$ & $\mathrm{x}_{3}$ \\
\hline \multirow{3}{*}{ Social protection } & $\mathrm{y}_{1}$ & 7 & 4 & 6 \\
\cline { 2 - 5 } & $\mathrm{y}_{2}$ & 7 & 7 & 6 \\
\cline { 2 - 5 } & $\mathrm{y}_{3}$ & 7 & 4 & 6 \\
\hline
\end{tabular}

$I C R=0.778$

In the case of Poland, we have relatively strong social protection $\left(y_{1}\right)$ and a medium specialized education system $\left(x_{2}\right)$. The Institutional Complementarity Ratio amounts to 0.778 .

Figure 11. Social protection vs. education system. Distribution of ICR after 1000 simulations

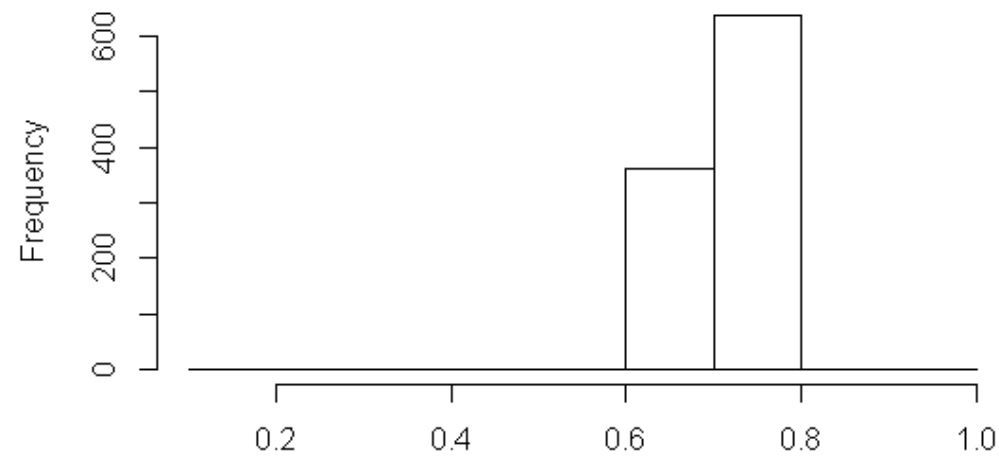

$C R 1000=0.738$

Average Institutional Complementarity Ratio after 1000 simulations amounts to 0.738 .

Case 4. Labour market vs. financial system

\begin{tabular}{|c|c|c|c|c|}
\cline { 3 - 5 } \multicolumn{2}{c|}{} & \multicolumn{3}{c|}{ Financial system } \\
\cline { 3 - 5 } \multicolumn{2}{c|}{} & $\mathrm{x}_{1}$ & $\mathrm{x}_{2}$ & $\mathrm{x}_{3}$ \\
\hline \multirow{3}{*}{ Labour market } & $\mathrm{y}_{1}$ & 4 & 7 & 8 \\
\cline { 2 - 5 } & $\mathrm{y}_{2}$ & 6 & 7 & 8 \\
\cline { 2 - 5 } & $\mathrm{y}_{3}$ & 7 & 7 & 6 \\
\hline
\end{tabular}

$I C R=0.111$

In the case of Poland, we have relatively weak trade unions $\left(y_{l}\right)$ and no excessive role of the stock exchange $\left(x_{1}\right)$. The Institutional Complementarity Ratio amounts to 0.111. 
Figure12. Labour market vs. financial system. Distribution of ICR after 1000 simulations

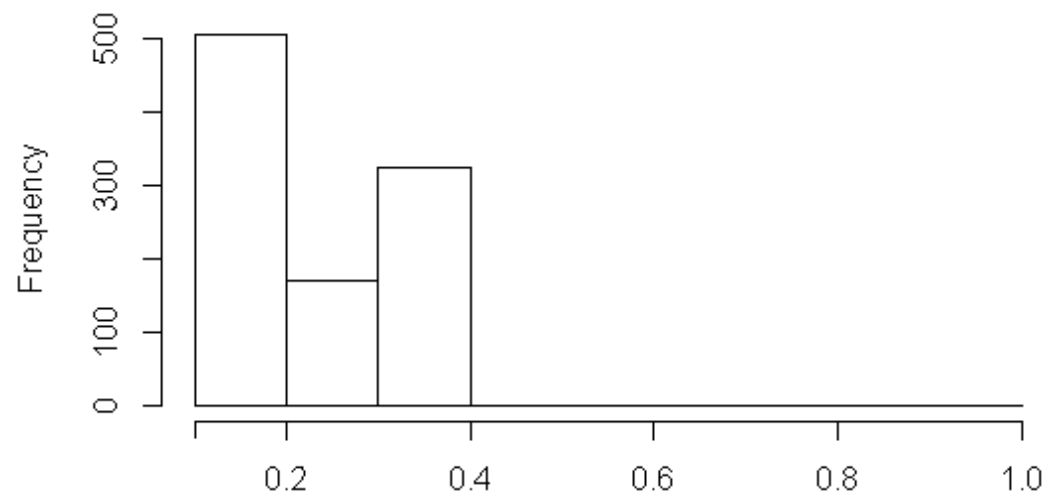

$I C R_{1000}=0.202$

The average Institutional Complementarity Ratio after 1000 simulations amounts to 0.202 .

Case 5. Labour market vs. education system

\begin{tabular}{|c|c|c|c|c|}
\cline { 3 - 5 } \multicolumn{2}{c|}{} & \multicolumn{3}{c|}{ Education system } \\
\cline { 2 - 5 } \multicolumn{2}{c|}{} & $\mathrm{x}_{1}$ & $\mathrm{x}_{2}$ & $\mathrm{x}_{3}$ \\
\hline \multirow{3}{*}{ Labour market } & $\mathrm{y}_{1}$ & 7 & 4 & 6 \\
\cline { 2 - 5 } & $\mathrm{y}_{2}$ & 7 & 6 & 6 \\
\cline { 2 - 5 } & $\mathrm{y}_{3}$ & 7 & 7 & 6 \\
\hline
\end{tabular}

$I C R=0.667$

In the case of Poland, we have relatively weak trade unions $\left(y_{1}\right)$ and a medium specialized education system $\left(x_{2}\right)$. The Institutional Complementarity Ratio amounts to 0.667.

Figure 13. Labour market vs. education system. Distribution of ICR after 1000 simulations

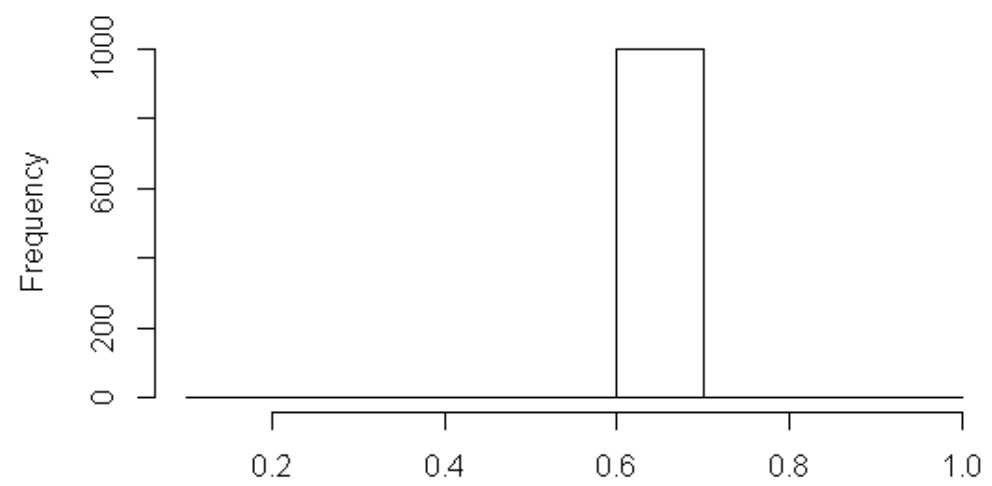

$I C R_{1000}=0.667$ 
The average Institutional Complementarity Ratio after 1000 simulations amounts to 0.667 .

Case 6. Financial system vs. Education system

\begin{tabular}{|c|c|c|c|c|}
\cline { 3 - 5 } \multicolumn{2}{c|}{} & \multicolumn{3}{c|}{ Education system } \\
\cline { 3 - 5 } \multicolumn{2}{c|}{} & $\mathrm{x}_{1}$ & $\mathrm{x}_{2}$ & $\mathrm{x}_{3}$ \\
\hline \multirow{3}{*}{ Financial system } & $\mathrm{y}_{1}$ & 8 & 4 & 6 \\
\cline { 2 - 5 } & $\mathrm{y}_{2}$ & 7 & 7 & 6 \\
\cline { 2 - 5 } & $\mathrm{y}_{3}$ & 7 & 7 & 6 \\
\hline
\end{tabular}

$I C R=0.778$

In the case of Poland, we do not have an excessive role of the stock exchange $\left(y_{l}\right)$ and a medium specialized education system $\left(x_{2}\right)$. The Institutional Complementarity Ratio amounts to 0.778 .

Figure 14. Labour market vs. education system. Distribution of ICR after 1000 simulations

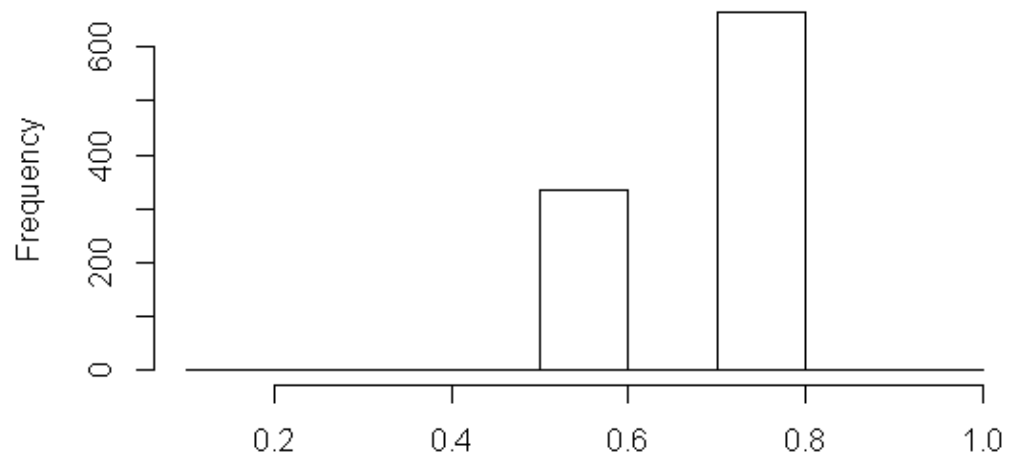

$I C R_{1000}=0.704$

The average Institutional Complementarity Ratio after 1000 simulations amounts to 0.704 .

\section{Conclusions}

Our analysis revealed that, in general, institutional complementarity in Poland is at a satisfactory level. In five out of six cases Institutional Complementarity Ratio was above 0.5 . An especially high level of complementarity can be observed in the case of interaction between social protection and the education system (the average ICR amounted to 0.738 ).

However, in the case of interaction between the labour market and the financial system, we obtained an average Institutional Ratio at the level of 0.202, 
which indicates a low level of institutional complementarity between those two institutional areas. It is worth noting that in the case of Poland there are relatively weak trade unions $\left(y_{l}\right)$ and no excessive role of the stock exchange $\left(x_{l}\right)$. Institutional complementarity in such a case could emerge if there were increased market capitalization and low trade union density (Gatti, Rault, Vaubourg 2010). This may indicate that in order to achieve a higher level of institutional complementarity between the labour market and the financial system in Poland there should be further development of the stock exchange (higher market capitalization).

Further research in this area could include more institutional areas and more possible institutional forms.

\section{Summary}

After more than two decades since the first stage of the economic transition and one decade after joining the European Union, Poland has achieved a relatively high level of institutional complementarity. However, in the case of interaction between the labour market and the financial system, there is a very low level of institutional complementarity. Furthermore, the Polish model of capitalism seems to be quite different from other countries from the peer group of transition economies (for example the Czech Republic or Hungary).

\section{Bibliography}

Amable B. (2003), The Diversity of Modern Capitalism, Oxford University Press. Arthur, B. (1994), Increasing Returns and Path Dependence in the Economy, Ann Arbor: University of Michigan Press.

Estevez-Abe M., Iversen T., Soskice D. (2001), Social Protection and the Formation of Skills: A Reinterpretation of the Welfare State, chapter in "Varieties of Capitalism: The Institutional Foundations of Comparative Advantage" edited by Hall P. and Soskice D., Oxford University Press.

Friedman M., Friedman R. (1979), Free to Choose, Chicago Press.

Gatti D., Rault Ch., Vaubourg A. (2010), Unemployment and finance: how do financial and labour market factors interact?, William Davidson Institute Working Paper No. 973, January 2010.

Gross D., Steinherr A. (2005), Economic Transition in Central and Eastern Europe, Cambridge University Press.

Hoffmann I. (2010), Principal Component Analysis with FactoMineR, Institutfür Statistik und Wahrscheinlichkeitstheorie.

Kolodko G., Rutkowski M. (1991), The Problem of Transition from a Socialist to a Free Market Economy: The Case of Poland, "The Journal of Social, Political and Economic Studies”, Summer, 1991 Vol. 16, No. 2. 
Krugman P., Wells R. (2005), Microeconomics, New York: Worth Publishers.

Levine R. (1990), Stock Markets, Growth and Policy, "Board of Governors of the Federal Reserve System International Finance Discussion Papers", No. 374. Matthews R.C.O. (1986), The Economics of Institutions and the Sources of Economic Growth, "Economic Journal 96:4, pp. 903-918.

North D.C. (1990), Institutions, Institutional Change and Economic Performance, Cambridge University Press.

Sen A. (2007), Capability and well-being, chapter in "The Philosophy of Economics. An Anthology" edited by Hausman D.M., Cambridge University Press.

Topkis, D.M. (1998), Supermodularity and Complementarity, Princeton: Princeton University Press.

Williamson O. (2000), The New Institutional Economics: Taking Stock, Looking Ahead, "Journal of Economic Literature", Vol. XXXVIII (September 2000), pp. 595-613. Yildiz M. (2010), Lecture Notes on Supermodular Games, MIT Open Course Ware.

\section{Abstract}

Poland is one of the most significant examples of a transition country in Central and Eastern Europe. After 45 years of being a centrally planned economy Poland emerged at the end of the 1980's a free-market economy. In 2004 Poland became a member of the European Union, which was another milestone in the transition process. Undoubtedly, institutions were a very important factor in Poland's economic transition. It seems that the horizon of 25 years since the fall of communism has created a decent prospect to evaluate the balance of economic transition in terms of the quality of institutions. However, comparative studies do not analyse institutions separately, but consider them together in an institutional framework.

The purpose of this essay is to examine the scope of the institutional complementarity of Poland in terms of Diversity of Capitalism. The main thesis of the article is that after more than two decades since the first stage of the economic transition, and one decade after joining the European Union, Poland's institutional complementarity is, in general, at a satisfactory level. However, there is a very low level of institutional complementarity in the case of interaction between the labour market and the financial system. Furthermore, the Polish model of capitalism seems to be quite different from other countries from the peer group of transition economies (for example the Czech Republic or Hungary). The research method which was used in this essay includes statistical methods (in particular the K-Nearest Neighbours Method, K-Mean Method and Principal Component Analysis).

Keywords: institutional complementarity, diversity of capitalism, cluster analysis, k-nearest neighbours method, k-mean method, principal component analysis 


\section{Streszczenie}

\section{Komplementarność instytucjonalna Polski a różnorodność kapitalizmu}

Polska to jeden z najbardziej znaczących przykładów transformacji gospodarczej w Europie Środkowej i Wschodniej. Po 45 latach funkcjonowania w warunkach gospodarki centralnie planowanej pod koniec lat 80 . XX w. polska gospodarka przekształciła się w gospodarkę wolnorynkową. W 2004 r. kraj przystąpił do Unii Europejskiej, co stanowiło kolejny kamień milowy w procesie transformacji. Niewątpliwie znaczącym czynnikiem, jeśli chodzi o transformację gospodarczą państwa, było otoczenie instytucjonalne. Wydaje się, że horyzont 25 lat od momentu upadku komunizmu stwarza odpowiednią perspektywę do oceny bilansu transformacji gospodarczej ze szczególnym uwzględnieniem jakości instytucji. Studia komparatystyczne nie analizują jednak poszczególnych instytucji osobno, tylko rozpatrują je razem z perspektywy ram instytucjonalnych.

Celem niniejszego opracowania jest zbadanie zakresu komplementarności instytucjonalnej Polski w ujęciu różnorodności kapitalizmu (Diversity of Capitalism). Główną tezą artykułu jest to, że po ponad dwóch dekadach od pierwszego etapu transformacji gospodarczej oraz po dekadzie od przystąpienia do Unii Europejskiej komplementarność instytucjonalna Polski jest zasadniczo na satysfakcjonującym poziomie. Możemy jednak zaobserwować niski poziom komplementarności instytucjonalnej w przypadku interakcji między rynkiem pracy a systemem finansowym. Ponadto polski model kapitalizmu wydaje się nieco odmienny od modeli innych państw z grupy porównawczej, tj. krajów, które przeszły transformację gospodarczą (w szczególności od Czech czy Węgier). Metoda badawcza użyta w tym artykule opiera się na analizie statystycznej (w szczególności na metodzie K-najbliższych sąsiadów, metodzie K-średnich oraz analizie głównych składowych).

Słowa kluczowe: komplementarność instytucjonalna, różnorodności kapitalizmu, klasteryzacja, metoda K-najbliższych sąsiadów, metoda K-średnich, analiza głównych składowych

JEL: C38, E02 


\section{Appendices}

\section{Appendix 1}

Data set after imputation

\begin{tabular}{|c|c|c|c|c|c|}
\hline & Gini & TUD & MCAP & VE & HDI \\
\hline Australia & 32.42000 & 18.197189 & 83.838378 & 34.712080 & 93.3 \\
\hline Austria & 26.90207 & 27.447012 & 26.016498 & 39.336395 & 88.1 \\
\hline Belgium & 26.43390 & 55.020519 & 60.149587 & 38.912678 & 88.1 \\
\hline Canada & 31.55793 & 27.462644 & 110.687749 & 15.533966 & 90.2 \\
\hline Chile & 50.30000 & 15.317393 & 117.676757 & 22.485892 & 82.2 \\
\hline Czech Republic & 25.60746 & 13.396150 & 17.974855 & 38.587471 & 86.1 \\
\hline Denmark & 25.27000 & 67.204191 & 69.771256 & 26.906646 & 90.0 \\
\hline Estonia & 32.25881 & 6.413866 & 10.290753 & 19.310191 & 84.0 \\
\hline Finland & 26.05091 & 68.633599 & 62.041239 & 32.295640 & 87.9 \\
\hline France & 30.90000 & 7.744868 & 67.864813 & 19.696731 & 88.4 \\
\hline Germany & 29.30900 & 17.869235 & 42.066595 & 18.887961 & 91.1 \\
\hline Greece & 33.53777 & 21.264870 & 17.867544 & 17.674545 & 85.3 \\
\hline Hungary & 28.99900 & 10.550839 & 16.621640 & 16.095378 & 81.8 \\
\hline Iceland & 25.06097 & 82.603108 & 19.916765 & 22.027846 & 89.5 \\
\hline Ireland & 30.17415 & 31.225400 & 49.112907 & 16.177321 & 89.9 \\
\hline Italy & 32.14053 & 36.275686 & 22.968815 & 36.017278 & 87.2 \\
\hline Japan & 33.57502 & 17.972384 & 61.818735 & 11.641705 & 89.0 \\
\hline Korea & 30.70000 & 9.886705 & 96.537987 & 9.904868 & 89.1 \\
\hline Luxembourg & 27.61304 & 32.818207 & 124.952662 & 30.573954 & 88.1 \\
\hline Mexico & 48.16966 & 13.617932 & 44.254023 & 16.633084 & 75.6 \\
\hline Netherlands & 27.80000 & 17.694896 & 79.088014 & 48.195784 & 91.5 \\
\hline New Zeland & 32.30000 & 20.507572 & 46.542299 & 13.970239 & 91.0 \\
\hline Norway & 24.96000 & 53.272197 & 50.586956 & 29.032057 & 94.4 \\
\hline Poland & 30.38715 & 12.516084 & 35.817799 & 29.336394 & 83.4 \\
\hline Portugal & 34.13561 & 20.537434 & 30.059442 & 25.197853 & 82.2 \\
\hline Slovakia & \begin{tabular}{|l|}
6.14698 \\
\end{tabular} & 16.761479 & 4.971166 & 34.191267 & 83.0 \\
\hline Slovenia & 24.50242 & 23.115449 & 13.996031 & 35.935290 & 87.4 \\
\hline Spain & 34.39253 & 17.473472 & 73.399048 & 17.688507 & 86.9 \\
\hline Sweden & 27.34200 & 67.505935 & 103.060473 & 26.953219 & 89.8 \\
\hline Switzerland & 28.89541 & 16.211944 & 161.990841 & 34.651958 & 91.7 \\
\hline Turkey & 41.20000 & 4.541725 & 39.141707 & 23.590092 & 75.9 \\
\hline United Kingdom & 34.43898 & 25.838645 & 115.469554 & 9.700481 & 89.2 \\
\hline United States & 38.88385 & 11.078848 & 115.498993 & \begin{tabular}{|l|}
17.227804 \\
\end{tabular} & 91.4 \\
\hline
\end{tabular}




\section{Appendix 2}

Data set after categorization

\begin{tabular}{|c|c|c|c|c|c|}
\hline & Gini & TUD & MCAP & VE & HDI \\
\hline Australia & 1 & 1 & 2 & 2 & 9 \\
\hline Austria & 1 & 1 & 1 & 3 & 6 \\
\hline Belgium & 1 & 2 & 2 & 3 & 6 \\
\hline Canada & 1 & 1 & 3 & 1 & 7 \\
\hline Chile & 3 & 1 & 3 & 1 & 4 \\
\hline Czech Republic & 1 & 1 & 1 & 3 & 6 \\
\hline Denmark & 1 & 3 & 2 & 2 & 7 \\
\hline Estonia & 1 & 1 & 1 & 1 & 5 \\
\hline Finland & 1 & 3 & 2 & 2 & 6 \\
\hline France & 1 & 1 & 2 & 1 & 7 \\
\hline Germany & 1 & 1 & 1 & 1 & 8 \\
\hline Greece & 2 & 1 & 1 & 1 & 5 \\
\hline Hungary & 1 & 1 & 1 & 1 & 3 \\
\hline Iceland & 1 & 3 & 1 & 1 & 7 \\
\hline Ireland & 1 & 2 & 1 & 1 & 7 \\
\hline Italy & 1 & 2 & 1 & 3 & 6 \\
\hline Japan & 2 & 1 & 2 & 1 & 7 \\
\hline Korea & 1 & 1 & 2 & 1 & 7 \\
\hline Luxembourg & 1 & 2 & 3 & 2 & 6 \\
\hline Mexico & 3 & 1 & 1 & 1 & 1 \\
\hline Netherlands & 1 & 1 & 2 & 3 & 8 \\
\hline New Zeland & 1 & 1 & 1 & 1 & 8 \\
\hline Norway & 1 & 2 & 1 & 2 & 9 \\
\hline Poland & 1 & 1 & 1 & 2 & 4 \\
\hline Portugal & 2 & 1 & 1 & 2 & 4 \\
\hline Slovakia & 1 & 1 & 1 & 2 & 4 \\
\hline Slovenia & 1 & 1 & 1 & 3 & 6 \\
\hline Spain & 2 & 1 & 2 & 1 & 6 \\
\hline Sweden & 1 & 3 & 2 & 2 & 7 \\
\hline Switzerland & 1 & 1 & 3 & 2 & 8 \\
\hline Turkey & 2 & 1 & 1 & 2 & 1 \\
\hline United Kingdom & 2 & 1 & 3 & 1 & 7 \\
\hline United States & 2 & 1 & 3 & 1 & 8 \\
\hline
\end{tabular}




\section{Appendix 3}

GNU R code with the most important functions and objects, which were used to calculations and statistical analysis

\#com03 ations and statistical 1

\#com04 ations and statistical 2

library (class)

library (stargazer)

library (FactoMineR)

library (gtools)

\# dividing institutional areas into forms and HDI into categories

cat $<$-function $(\mathrm{x}, \mathrm{f}, \mathrm{h})\{$

\# Normalization

$\mathrm{p}<-$ function $(\mathrm{x})\{$

for $(i$ in $1: 5)\{$

$x[, i]<-((x[, i]-\min (x[, i])) /(\max (x[, i])-\min (x[, i])))$

$\mathrm{x}$

$X$
\}

$\mathrm{y}<-\mathrm{p}(\mathrm{x})$

\# Discretization

$r<-$ function $(\mathrm{x}, \mathrm{f}, \mathrm{h})\{$

for $(i$ in $1: 4)\{$

$x[$, i $]<-\operatorname{cut}\left(x[, i]\right.$, breaks $=$ seq $\left(\right.$ from $\left.=0, t_{0}=1, b y=1 / f\right)$, labels=FALSE, dig.

$1 \mathrm{ab}=\operatorname{seq}(1, \mathrm{f}, \mathrm{by}=1)$, include. lowest=TRUE) \}

$\mathrm{x}[, 5]<-\operatorname{cut}\left(\mathrm{x}[, 5]\right.$, breaks $=\mathrm{seq}\left(\right.$ from $\left.=0, \mathrm{to}_{\mathrm{o}}=1, \mathrm{by}=1 / \mathrm{h}\right)$, labels=FALSE, dig. $1 \mathrm{ab}=\operatorname{seq}(1, \mathrm{~h}, \mathrm{by}=1)$, include. lowest=TRUE)

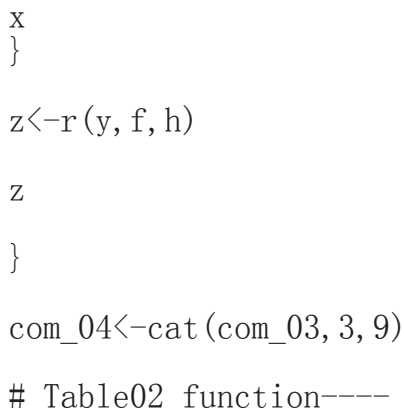


set. seed (123)

table $02<$-function $(\mathrm{kr}, \mathrm{x}, \mathrm{y}, \mathrm{f}, \mathrm{n})\{$

$\# \mathrm{kr}-$ country

\# $\mathrm{x}, \mathrm{y}-$ columns in the matrix of discretional data

\# $\mathrm{f}$ - number of forms in institutional areas

$\# \mathrm{n}$ - number of nearest neighbours in knn

$\mathrm{m}<-\operatorname{matrix}\left(\operatorname{rep}\left(0, f^{\wedge} 2\right), n c o l=f\right)$

ind $<-$ as. vector $($ com_04 $[\mathrm{kr}, \mathrm{c}(\mathrm{x}, \mathrm{y})])$

$\mathrm{m}[$ ind $[1]$, ind $[2]]<-$ com_04 $[\mathrm{kr}, 5]$

wzk $<-$ which $(m==0$, arr. ind=TRUE) \# coordinates of the null cells in table train<-com_04[, c $(\mathrm{x}, \mathrm{y})]$

cl<-as. factor (as. vector (com_04[, 5]))

$\mathrm{k}<-\mathrm{n}$

test $<-$ wzk

$\mathrm{kn}<-$ as. numeric (as. vector $(\mathrm{knn}($ train=train, test=test, $\mathrm{cl}=\mathrm{cl}, \mathrm{k}=\mathrm{n})))$

for (i in 1:dim(wzk) [1]) \{

$\mathrm{a}<-$ as. vector $($ wzk $[\mathrm{i}]$,

$\mathrm{m}[\mathrm{a}[1], \mathrm{a}[2]]<-\mathrm{kn}[\mathrm{i}]$

\}

rownames $(\mathrm{m})<-1$ etters $[1: \mathrm{f}]$

colnames $(\mathrm{m})<-1$ etters $[1: \mathrm{f}]$

\# Complementarity

$\mathrm{k}<-$ permutations $(\mathrm{n}=\mathrm{f}, \mathrm{r}=4, \mathrm{v}=1$ : $\mathrm{f}$, repeats. allowed=TRUE)

$\mathrm{g}\langle-$ which $(\mathrm{k}[, 1]\langle=\mathrm{k}[, 3] \mid \mathrm{k}[, 2]\rangle=\mathrm{k}[, 4])$

$\mathrm{h}<-\mathrm{k}[-\mathrm{g}$,

$\mathrm{s}<-$ numeric $(\operatorname{dim}(\mathrm{h})[1])$

for $(i$ in $1: \operatorname{dim}(h)[1])\{$

$\mathrm{s}[\mathrm{i}]<-$ ifelse $(\mathrm{m}[\mathrm{h}[\mathrm{i}, 1], \mathrm{h}[\mathrm{i}, 2]]+\mathrm{m}[\mathrm{h}[\mathrm{i}, 3], \mathrm{h}[\mathrm{i}, 4]]<=$

$m[\max (h[i, 1], h[i, 2]), \max (h[i, 3], h[i, 4])]+$

\}

$\operatorname{m}[\min (h[i, 1], h[i, 2]), \min (h[i, 3], h[i, 4])], 1,0)$

wk $<-$ mean $(\mathrm{s})$

\# Table’ s graphics

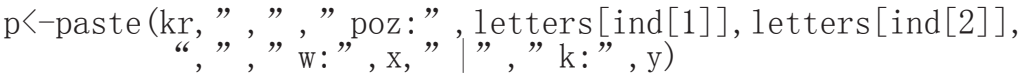

$\mathrm{t}<-$ stargazer $(\mathrm{m}$, type $=$ “text”, title $=\mathrm{p}, \operatorname{digits}=1$, out=" table. txt")

$1<-1$ ist $($ table02=t, complementarity=wk)

\} 
\# Clustering----

$\mathrm{km}<-$ kmeans (com_03[, 1:4], centers $=5)$

$\mathrm{c} 1<-$ LETTERS [as. vector $(\mathrm{km} \$$ cluster $)]$

$\mathrm{d}<$-data. frame (com_03 [, 1:4], c1)

pca $<-P C A(d, n c p=4$, quali. $\sup =5)$

plot $($ pca, choix $=$ " ind" , habillage $=5$ )

\# Data visualization----

w1<-table02 (,Poland” , "Gini” , ” TUD” , 3, 5)

w1 [ $[1]]$

w1 $[[2]]$

w2<-table02 („Poland” , "Gini” , "MCAP” , 3, 5)

w2 [[1]]

w2 $[[2]]$

w3<-table02 (,Poland” , " Gini” , ”VE” , 3, 5)

w3 [ $[1]]$

w3 $[[2]]$

w4<-table02 (,Poland” , ” TUD” , ” MCAP” , 3, 5)

w4 [[1]]

$\mathrm{w} 4[[2]]$

w5<-table02 (,Poland” , ” TUD” , ” VE” , 3, 5)

w5 [ [1]]

w5 $[[5]]$

w6<-table02 (,Poland” , "MCAP” , " VE” , 3, 5)

w6 [ [1]]

w6 $[[2]]$ 